\title{
TEACHERS' PERCEPTION ON THE CHALLENGES OF UTILIZING PROBLEM- BASED LEARNING IN TEACHING COMPUTER SCIENCE IN PUBLIC SENIOR SECONDARY SCHOOLS IN PORT HARCOURT METROPOLIS
}

\author{
Eunice C. Victor-Ishikaku ${ }^{1}$ and Gift Ukpai ${ }^{2}$ \\ Department of Curriculum Studies and Instructional Technology, Faculty of Education, \\ Ignatius Ajuru University of Education, Port Harcourt. \\ ${ }^{1}$ Email: eunicevictor886@yahoo.com \\ ${ }^{2}$ Email: giftedtech031@gmail.com
}

\section{Cite this article:}

Eunice C.V., Gift U. (2021), Teachers' Perception on the Challenges of Utilizing Problem-Based Learning in Teaching Computer Science in Public Senior Secondary Schools in Port Harcourt Metropolis. British Journal of Contemporary Education 1(1), 52-63. DOI: 10.52589/BJCEGPXJAQES.

\section{Manuscript History}

Received: 13 May 2021

Accepted: 5 June 2021

Published: 22 June 2021

Copyright $(9) 2020$ The Author(s). This is an Open Access article distributed under the terms of Creative Commons AttributionNonCommercial-NoDerivatives 4.0 International (CC BY-NC-ND 4.0 ), which permits anyone to share, use, reproduce and redistribute in any medium, provided the original author and source are credited.
ABSTRACT: This study investigated teachers' perception on the challenges of utilizing Problem-Based Learning in teaching computer science in public senior secondary schools in Port Harcourt Metropolis, Rivers State, Nigeria. This study adopted descriptive research design. Two research questions and hypotheses were formulated to guide this study. The population for the study comprised one hundred (100) computer science teachers in the thirty six (36) public senior secondary schools located in Port Harcourt metropolis of Rivers State. Census sampling procedure was used to obtain one hundred (100) computer science teachers as the sample size due to the manageable size of the entire population. A structured questionnaire titled "Teachers' Challenges of Utilizing Problem-Based Learning in Teaching Computer Science in Public Senior Secondary Schools in Port Harcourt Metropolis" (CUPOBALETCOS) was used for collection of data. The questionnaire was validated by experts. Pearson Moment Correlation Coefficient was used to determine the reliability of the instrument which gave a value of 0.84 . Mean and standard deviation were used to analyse data and test of hypotheses was done with the use of z-test statistics. Results obtained from the findings revealed that the challenges of utilizing the Problem-Based Learning approach in teaching computer science and the aids to the utilization of this approach in teaching computer science were highly perceived by computer science teachers in senior secondary schools in the metropolis of Port Harcourt, Rivers State in Nigeria. Based on the findings, it was recommended that: Professional programmes, in addition to training exercise, need to be carried out frequently to enable teachers to get acquainted with the utilization of innovative teaching approaches and combat the associated challenges. Administrative duties or demands of teachers should be adjusted in order to have enough time for utilization of innovative teaching practices in the classroom. Curriculum for Problem-Based Learning should be fully introduced in the secondary and primary school education, so as to have facilitators who can help students by facilitating the Problem-Based Learning practices in the learning environment.

KEYWORDS: Problem-Based Learning, Computer Science, Perception, Utilization, Challenges and Aids. 


\section{INTRODUCTION}

Crucial to note is the fact that the drive of education is not limited to making students literate. It involves enlightening students' understanding, skills, independence and their skill to think in a rational manner. This however, requires adopting and utilizing innovative teaching approaches that will be suitable to achieve these purposes. Effective transfer of information is by means of schools, but teachers are the most effective vehicles for driving knowledge to the young generation of learners and their families at large (Victor-Ishikaku \& Nyenwe, 2014). If teachers, as the vehicles, fail to adopt effective approaches of transferring knowledge and skills to learners, the objectives of teaching and learning would not be achieved.

There are varieties of roles a teacher is expected to carry out in order to fully dispense his teaching activities. A teacher's role is not just to teach an already defined and static curriculum, but to ensure knowledge by means of support, guidance, and monitoring of the learning process (Christiansen, Kuure, Mørch \& Lindström, 2013). In relation to this, teachers of the 21st century are expected to shift from the traditional teaching approach, which only dwells on predefined teaching and static curriculum, and embrace innovative teaching approaches.

As an innovative teaching approach, Problem-Based Learning (PBL) helps students to learn by solving real-life problems. This was supported by the definition of Savery (2015), which viewed PBL as an approach of instruction that focuses on learners, so as to empower them to carry out discovery, incorporate theory and practice, and ensure application of knowledge and abilities to solve a given problem. A relationship exists between PBL and other instructional approaches like Project-Based Learning due to the fact that both approaches focus on providing real applications of contents and skills, questions in open-ended form, building 21st century skills among learners, and encouraging independent enquiry, which supersedes the traditional approach of instruction (Larner, 2014).

The application of PBL has widely taken place in fields like nursing, law and business, as observed by Walker and Leary (2009). This is not exceptional in the field of computer science. Students' success in the field of computer science is dependent on their knowledge acquisition and familiarity with various sets of skills, such as having a passion for mathematics, acquiring logical skills, problem solving skills, algorithmic intelligence and developing skills needed for programming (Oliveira, Santos \& Garcia, 2013). Unfortunately, numerous students struggle to develop these skills, especially during their secondary education. Some even lack basic knowledge and practices required for use of computer systems to perform basic activities. This occurs as a result of the teaching methods utilized by their teachers during the basic level of education; lack of practicals after theory is predominant among learners (Santos, Batista, Cavalcanti, Albuquerque \& Meira, 2009). Giving theory and practicals to students will enable them to connect what they learn, thus, linking their previous knowledge to new knowledge; hence, the need to utilize PBL in teaching computer science.

There are challenges in the utilization of the PBL approach that could hinder computer science teachers from utilizing it. MacMath, Sivia and Britton (2017) posited those challenges related to the utilization of PBL, which can impact on teachers perception of PBL, are broadly categorized into three: beliefs of teachers, context and teachers' practice. 


\section{Teachers' Beliefs}

Research reveals that effective utilization of PBL involves a momentous adjustment of practice for a great number of teachers (Ertmer \& Simons, 2006). It requires many to reconsider their views on teaching and learning, rethink their part in the classroom and review the assessment of their students' potential. As a result, professional development related to PBL implementation is key to its successful utilization in the classroom; in particular, if the professional development entails exposing teachers to real PBL learning proficiencies. This shows that teachers of computer science need to reconsider their views about teaching and learning activities which will help them effectively utilize PBL. It requires that they develop themselves professionally, so as to be acquainted with innovative teaching approaches that call for change in their teaching practice.

\section{Context}

There are aspects that cannot be controlled by the teacher which can pose a challenge to the utilization of PBL. Examples of such aspects are culture of the school, policy of education, continuous change or teaching staff, limits of standardized tests, educational policy, and maintenance of technology. As a result of these factors, PBL can be effectively implemented when there is support from the school administration, other teachers within the same school, and if fused into the school culture. Students find it difficult to understand the steps involved in learning with the Problem-Based Learning approach. As a result, it requires a comparatively long time; teachers finds it challenging to bring together problems in the real world, which can lead to the anticipated idea and the lack of teachers' preparation before teaching related with the worksheets and the media, because of the demands of administrative duties of teachers (Broto, Dewi \& Riyadi, 2018).

\section{Teachers' Practice}

Teachers' practice, as a challenge on the utilization of PBL, involves the following aspects:

Classroom interactions: Students' misconduct and/or disconnection, which occurs when they collaboratively or self-reliantly work for lengthy periods of time, can pose an issue or challenge to the teacher in the practice of utilizing PBL. Additionally, some students feel uncomfortable due to the intellectual and collective demands of PBL placed on them, which in turn leads to frustration and anxiety especially for higher achieving students. This however results in difficulty in organizing a large number of students in a PBL setting.

Technology: The use of technology is essential to PBL, but teachers find it challenging to successfully incorporate technology since they depend on the use of computers and the integration of other technology, which demand the allocation of time for giving instruction to students (ChanLin, 2008; Krajcik \& Shin, 2014).

Assessment: There is a perceived tension between the learning evaluated on standardized tests and the performance-based assessment typically taking place in PBL classrooms. Additionally, Grant and Branch (2005), cited in MacMath et al. (2017), and Krajik and Shin (2014) revealed other problems on the aspect that teachers are faced with limited time to constantly assess the performance of students by giving them feedbacks or involving them in self-assessment. 
Effective utilization of PBL demands for implementation of criteria that will help the teacher to adopt it as an innovative and effective approach to teaching. Azer (2011) asserted that implementing PBL in Schools and tertiary institutions is really demanding. The concern of the demand lies in a process that requires resources, planning and organization. However, Azer (2011) further discussed the aids for implementing or utilizing what they tagged as "pure PBL". These criteria can aid computer science teachers to utilize the PBL approach in teaching. They are thus indicated as: preparation of school for adjustment on teaching approach; planning the new PBL curriculum and outlining educational outcomes; making quest for guidance from experts of PBL; planning, organization and management of PBL; offering training to facilitators of PBL and outlining targets of a facilitator; familiarizing students with the PBL approach; varying the method of assessment for the suitability of the PBL approach; boosting responses from students and teachers; management of resources and facilities used for sustenance of selfdirected learning; and making continuous appraisal and modifications.

Specifically in computer science and other related fields, students are expected to be educated in a way that will aid them to grow and cope with fast changes and advancements in today's world. Not only expecting them to align with changes in today's world, but students should be expected to establish the manner for these changes. Passive acquisition of knowledge will not drive for changes; it is not enough to meet up with such expectations. As a result, innovative approaches (specifically, Problem-Based Learning) need to be developed and utilized in the field of computing. Hence, this study focused on teachers' challenges of utilizing ProblemBased Learning in teaching computer science in public senior secondary schools in Port Harcourt metropolis.

\section{Statement of the problem}

It is sad to notice that most students in secondary schools do not have basic computer operations skills, let alone remarkable programming skills in computer science. Even when they proceed to study it as a course in a higher institution, they end up not understanding the course due to the traditional teaching approach being utilized by their instructors or teachers. Based on observations in schools, as supported by Broto et al. (2018), teachers regularly give students the theory and instruct them to memorize, thereby engaging them less in practical learning. This situation has affected computer operation and programming competency of students.

So, the challenge is, why are teachers not using PBL in teaching? Are there perceived challenges of teaching computer science with the PBL approach? What could aid teachers to utilize the PBL approach in teaching computer science? Based on these, this study examined teachers' perception on the challenges of utilizing Problem-Based Learning in teaching computer science in public senior secondary schools in Port Harcourt metropolis, Rivers State, Nigeria (Port Harcourt City and Obio-Akpor Local Government Area).

\section{Purpose of the study}

The main purpose of this study is to investigate computer science teachers' perception of the utilization of Problem-Based Learning in public senior secondary schools in Port Harcourt metropolis (Port Harcourt City and Obio-Akpor Local Government Area). Specifically, this study seeks to:

1. Ascertain teachers' perception on the challenges of utilizing Problem-Based Learning in teaching computer science 
2. Determine teachers' perception on the aids to the utilization of Problem-Based Learning approaches in teaching computer science.

\section{Research questions}

The following formulated research questions guided this study:

1. What are the teachers' perceptions on the challenges of utilizing a Problem-Based Learning approach in teaching computer science?

2. What are the teachers' perceptions on the aid to utilization of a Problem-Based Learning approach in teaching computer science?

\section{Hypotheses}

The following null hypotheses were formulated and tested at 0.05 level of significance for the purpose of this study:

1. There is no significant difference in the mean responses of male and female computer science teachers in Port Harcourt metropolis on the perceived challenges of utilizing a Problem-Based Learning approach in teaching computer science.

2. There is no significant difference in the mean responses of male and female computer science teachers in Port Harcourt metropolis on their perception of aid to utilization of Problem-Based Learning approach in teaching computer science.

\section{Definition of Terms}

Aids: The implementation of criteria that will help teachers adopt PBL for teaching computer science.

Challenges: The difficulties which require great effort and determination for teachers to adopt PBL in teaching computer science.

Computer Science: This is a subject taught in secondary schools and tertiary institutions, which requires students to master basic computer activities such as operation and programming. It is the subject of interest to the researcher.

Perception: The process by which teachers of computer science regard, analyze, and adopt Problem-Based Learning as an innovative teaching approach for improving teaching.

Problem-Based Learning (PBL): This is an innovative teaching approach that allows students to learn by solving real-life problems.

Utilization: Teachers' action of setting PBL to use in the teaching of computer science in secondary schools.

\section{Method}

This study employed the descriptive research design to establish computer science teachers' perception of the utilization of a Problem-Based Learning approach in teaching in secondary schools. The study was carried out in all public senior secondary schools in Port Harcourt 
metropolis; that is Port Harcourt City Local Government Area and Obio-Akpor Local Government Area of Rivers State. The target population for this study comprised the entire computer science teachers in the thirty six (36) public senior secondary schools in Port Harcourt metropolis of Rivers State. The entire one hundred (100) computer science teachers in public senior secondary schools in Port Harcourt City and Obio-Akpo Local Government Area formed the population. The entire population size of 100 computer science teachers was used as the sample size for the study. Due to the manageable size of the population census, sampling procedure was adopted for the study. This is in line with Kinglsey's assertion (2019), which indicated that a census sampling technique can be adopted where the population size of the study is manageable.

The instrument for this research was a structured questionnaire designed by the researcher, which is titled "Teachers' Challenges of Utilizing Problem-Based Learning in Teaching Computer Science in Public Senior Secondary Schools in Port Harcourt Metropolis" (CUPOBALETCOS). The questionnaire was made up of sections A and B. Section A was based on the personal information about teachers, local government area of school, qualification, professional training, and service duration. Section B contained the following: challenges of utilizing Problem-Based Learning in teaching computer science and aids to the utilization of the PBL approach in teaching computer science. The questionnaire was a 4-option rating scale of Very Highly Perceived - 5, Highly Perceived - 3, Moderately Perceived - 2, and Slightly Perceived - 1. The validity of the instrument was done by three experts in the area of study, who scrutinized the instrument of the research by evaluating the questionnaire.

The reliability coefficient was determined. This was done by a test-retest method using Pearson Product Moment Correlation Coefficient (PPMC) and the value was calculated to be 0.84 , which indicated that the correlation was high, that is, the instrument was reliable. The instrument was administered and collected the same day. Instructions about careful filling of the questionnaire was made known to the respondents. The researcher administered 100 copies of the questionnaire to the respondents and they were all filled and returned. Mean and standard deviation was used to analyse data obtained from samples. The mean ratings were interpreted using the boundary limits: Very Highly Perceived (3.50-4.00), Highly Perceived (2.50-3.49), Moderately Perceived (1.50-2.49) and Slightly Perceived (0.50-1.49). The data were analyzed and presented in Tables. z-test statistics was used to test the two null hypotheses at 0.05 level of significance. 


\section{RESULTS}

Research question 1: What are the teachers' perceptions on the challenges of utilizing ProblemBased Learning in teaching computer science?

Table 1: Teachers' perception of the challenges of utilizing PBL in teaching computer science.

\begin{tabular}{|c|c|c|c|c|c|c|c|}
\hline \multirow[t]{2}{*}{ S/No } & \multirow[t]{2}{*}{ Items } & \multicolumn{2}{|c|}{ Male Teachers } & \multirow{2}{*}{$\begin{array}{l}\mathrm{N}=40 \\
\text { Remark }\end{array}$} & \multicolumn{3}{|c|}{ Female Teachers $=60$} \\
\hline & & $\underline{x}$ & St.D & & $\underline{x}$ & St.D. & $\begin{array}{l}\text { Remar } \\
\mathbf{k}\end{array}$ \\
\hline 1. & $\begin{array}{l}\text { Difficulty in organizing } \\
\text { large number of students }\end{array}$ & 3.00 & 1.09 & $\mathrm{HP}$ & 3.01 & 0.85 & $\mathrm{HP}$ \\
\hline 2. & $\begin{array}{l}\text { Difficulty in integrating } \\
\text { technology }\end{array}$ & 3.18 & 0.98 & HP & 2.80 & 1.04 & HP \\
\hline 3. & $\begin{array}{l}\text { Time and administrative } \\
\text { Demands of teachers' } \\
\text { duties }\end{array}$ & 3.55 & 0.69 & VHP & 3.47 & 0.88 & $\mathrm{HP}$ \\
\hline 4. & $\begin{array}{l}\text { Difficulty in assessment of } \\
\text { students' performance }\end{array}$ & 2.35 & 1.23 & MP & 2.08 & 1.27 & MP \\
\hline 5. & $\begin{array}{l}\text { Lack of teachers' } \\
\text { professional development } \\
\text { and training on innovative } \\
\text { teaching practices }\end{array}$ & 3.65 & 0.7 & VHP & 3.62 & 0.62 & VHP \\
\hline & Grand Mean/ St.D. & 3.15 & 0.94 & HP & 3.00 & 0.93 & HP \\
\hline
\end{tabular}

Table 1 reveals the extent to which teachers perceived the challenges of utilizing the ProblemBased Learning (PBL) approach in teaching computer science. Male teachers had mean values that ranged from 2.35-3.65 while female teachers had mean values ranging from 2.08-3.62. There was not much variation in the values of the standard deviation. However, the grand mean values of 3.15 and 3.00 respectively showed that computer science teachers highly perceived difficulty in organizing large number of students; difficulty in integrating technology, time and administrative demands of teachers duties; difficulty in assessment of students' performance; and lack of teachers' professional development and training on innovative teaching practices, as challenges of utilizing Problem-Based Learning (PBL) approach in teaching computer science.

Research question 2: What are teachers' perceptions on the aids to utilization of ProblemBased Learning in teaching computer science? 
Table 2: Extent of teachers' perception on the aids to utilization of PBL in teaching computer science.

\begin{tabular}{|c|c|c|c|c|c|c|c|}
\hline \multirow[t]{2}{*}{ S/No } & \multirow[t]{2}{*}{ Items } & \multicolumn{2}{|c|}{ Male Teachers } & $\mathrm{N}=40$ & \multicolumn{3}{|c|}{ Female Teachers $=60$} \\
\hline & & $\underline{x}$ & St.D & Remark & $\underline{x}$ & St.D & Remark \\
\hline 6. & $\begin{array}{l}\text { Introducing students to PBL } \\
\text { practices }\end{array}$ & 2.05 & 1.03 & $\mathrm{MP}$ & 2.22 & 1.09 & $\mathrm{MP}$ \\
\hline 7. & $\begin{array}{l}\text { Promotion of better } \\
\text { environment for teaching } \\
\text { with PBL }\end{array}$ & 2.43 & 1.06 & MP & 2.20 & 1.09 & MP \\
\hline 8. & $\begin{array}{l}\text { Encouraging responses from } \\
\text { students and teaching staff }\end{array}$ & 3.70 & 0.57 & VHP & 3.48 & 0.85 & HP \\
\hline 9. & $\begin{array}{l}\text { Promoting continuous } \\
\text { evaluation of students' } \\
\text { performance for making } \\
\text { changes }\end{array}$ & 3.35 & 0.89 & HP & 3.38 & 1.02 & HP \\
\hline 10. & Organizing students to learn & 2.05 & 1.13 & MP & 2.07 & 1.10 & MP \\
\hline & Grand Mean/ St.D. & 2.72 & 0.94 & HP & 2.67 & 1.03 & HP \\
\hline
\end{tabular}

Table 2 shows the extent of teachers' perception on the aids to utilization of Problem-Based Learning in teaching computer science. Male teachers had mean values from the range of 2.053.70 while female teachers had mean values ranging from 2.07-3.48. There were not many differences in the value of the standard deviation. Hence, the grand mean value of 2.72 and 2.67 respectively indicated that computer science teachers highly perceived introducing students to PBL practices, promotion of better environment for teaching with PBL, encouraging responses from students and teaching staff, promoting continuous evaluation of students' performance for making changes, and organizing students to learn, as the aids to utilization of Problem-Based Learning in teaching computer science.

Hypothesis 1: There is no significant difference in the mean responses of male and female computer science teachers in Port Harcourt metropolis on the perceived challenges of utilizing a Problem-Based Learning approach in teaching computer science.

Table 3: z-test analysis on teachers' perception on the challenges of utilizing PBL in teaching computer science.

\begin{tabular}{lcccccccc}
\hline Respondents & & & & & $\begin{array}{c}\text { Level } \\
\text { of Sig. }\end{array}$ & z-cal & z-crit & Decision \\
\hline Male Teachers & 40 & 3.15 & 0.94 & & & & & \\
& & & & 98 & 0.05 & 0.88 & 2.000 & Accepted \\
Female Teachers & 60 & 3.15 & 0.93 & & & & & \\
\hline
\end{tabular}

Table 3 reveals the z-test result of mean responses of male and female computer science teachers on their perceived challenges of utilizing Problem-Based Learning in teaching computer science. The table revealed a z-calculated (z-Cal.) value of 0.88 at degree of freedom (df) 98 and 0.05 level of significance. Since the calculated value of 0 is less than the $\mathrm{z}$-critical 
value of 2.000, the hypothesis - there is no significant difference in the mean responses of male and female computer science teachers in Port Harcourt metropolis on the perceived challenges of utilizing Problem-Based Learning approach in teaching computer science-is accepted.

Hypothesis 2: There is no significant difference in the mean responses of male and female computer science teachers in Port Harcourt metropolis on their perception of aids to utilization of Problem-Based Learning approach in teaching computer science.

Table 4: z-test analysis for teachers' perception on the aids to utilization of PBL in teaching computer science.

\begin{tabular}{lcccccccc}
\hline Respondents & $\mathbf{N}$ & $\underline{X}$ & St.D. & Df & $\begin{array}{c}\text { Level } \\
\text { of Sig. }\end{array}$ & z-cal & z-crit & Decision \\
\hline Male Teachers & 40 & 2.72 & 0.94 & & & & & \\
& & & & & & & & \\
Female Teachers & 60 & 2.67 & 1.03 & & & & & \\
\end{tabular}

Table 4 indicates the z-test result of male and female teachers on their perception of the aids to utilization of Problem-Based Learning in teaching computer science. The table indicated a zcalculated value of 0.25 at degree of freedom 98 and 0.05 level of significance (p). Since the calculated value of 0.25 is less than the $\mathrm{z}$-critical (z-crit.) value of 2.000 , the hypothesis - there is no significant difference in the mean responses of male and female computer science teachers in Port Harcourt metropolis on their perception of aid to utilization of Problem-Based Learning approach in teaching computer science-is accepted.

\section{DISCUSSION OF MAJOR FINDINGS}

The result of the study revealed that teachers' perception of the challenges of utilizing ProblemBased Learning in teaching computer science is high. Those challenges include: difficulty in organizing a large number of students, difficulty in integrating technology, being time demanding, difficulty in assessment of students' performance, and demands in administrative duties of teachers. This is in line with the assertion of Chanlin (2008) and Krajik and Shin (2014), which revealed that the use of technology is essential to PBL but teachers find it challenging to successfully incorporate technology since they depend on the use of computer and the integration of other technology, which demand the allocation of time for giving instruction to students. Grant and Branch (2005) and Krajik and Shin (2014) also supported these findings on the aspect of assessment and being time demanding, which revealed that teachers are faced with limited time to constantly assess the performance of students by providing feedback to them or involving them in self-assessment. Hence, there is a perceived tension between learning evaluated on a standardized test and Performance-Based Assessment that typically occurs in PBL classrooms. Broto, et al. (2018) also supported the findings on the aspect of organizing a large number of students and demands of administrative duties of teachers, as challenges of teaching with the PBL approach. They indicated that teachers find it difficult to build an atmosphere of interactive and motivating classes. Teachers also lack preparation before teaching topics related with the worksheet and the media as a result of the 
demands of the administrative duties of teachers. The findings also revealed that teachers' lack of professional development related to PBL implementation poses a challenge in utilizing the PBL approach in teaching computer science. Ertmer and Simons (2006) noted that it requires many to reconsider their views on teaching and learning, rethink their part in the classroom and review the assessment of their students' potential. As a result, professional development related to PBL implementation is key to its successful utilization in the classroom. In particular, if the professional development entails exposing teachers to real PBL learning proficiencies, the challenges of teaching computer science with PBL approach would be solved. However, it requires that they develop themselves professionally so as to be acquainted with innovative teaching approaches that call for change in their teaching practice.

The result of the findings also revealed that computer science teachers highly perceive the aids to utilization of PBL approach in teaching computer science. Those aids are introducing students to the PBL program, promoting a better environment for learning, boosting responses from students and teachers, promoting continuous evaluation of students' performance for making changes, and organizing students to learn. This is in line with the assertion of Azer and Sammy (2011), which shows that implementing PBL in Schools and tertiary institutions is really demanding and that concern of the demand lies in a process that requires resources, planning and organization. They further outlined the twelve aids for implementing or utilizing what they tagged "pure PBL" as: preparation of school for adjustment on teaching approach, development of new curriculum and working group, planning the new PBL curriculum and outlining educational outcomes, quest for guidance from experts on PBL, planning, organization and management of PBL, offering training to facilitators of PBL and outlining targets of a facilitator, familiarizing students with the PBL approach, varying the method of assessment for the suitability of the PBL approach, boosting responses from students and teachers, management of resources and facilities used for sustenance of self-directed learning and making continuous evaluation and changes. Broto et al. (2018) also supported this by analyzing the steps or criteria for effective utilization of PBL approach as: giving students orientation on a problem, organizing students to learn, offering of guidance to each learner and group as they investigate a given problem, development and presentation of investigative results and evaluation of the process of problem solving. All these can aid computer science teachers to utilize the PBL approach in teaching computer science.

\section{CONCLUSION}

There is a high extent on how teachers perceive the challenges of utilizing the PBL approach in teaching computer science. Practically, lack of teachers' professional development and training on innovative teaching practices, difficulty in assessing students' performance, time and administrative demands from teachers, difficulty in organizing a large number of students and integrating technology all determine teachers' perception on using the PBL approach for teaching computer science.

There are high perceptions on how computer science teachers can be aided to utilize PBL in teaching computer science such as: professionally developing teachers so as expose them to PBL learning experience, introducing students to PBL program, promoting better environment for PBL approach, promoting continuous evaluation from students and teaching staff so as to make changes on improving the teaching approach, and organizing students to learn. If these 
are not done, it will discourage or affect teachers' and students' effectiveness in teaching and learning respectively.

\section{RECOMMENDATIONS}

With regard to the findings on teachers' perception on challenges of utilizing Problem-Based Learning in teaching computer science in public senior secondary schools in Port Harcourt metropolis, the following are recommendations:

1. Professional programmes and training exercises should be carried out frequently by educational technologists, to enable teachers to get acquainted with the utilization of innovative teaching approaches and combat the associated challenges, so as to effectively achieve the teaching-learning objectives.

2. Educational and school heads should make adjustments on the administrative duties or demands of teachers. This would enable teachers to have enough time to utilize innovative teaching practices in the classroom, so as to make the learning environment reflect the real situation of societal needs.

3. There should be introduction of PBL curriculum into the secondary and primary school education, so as to have facilitators who are capable of facilitating PBL practices in the learning environment.

\section{REFERENCES}

Azer, S. A. (2011). Introducing a problem-based learning program: 12 tips for success. Medical Teacher. 33 (10): 808-13.

ChanLin, L.J. (2008). Technology integration applied to project-based learning in science. Innovations in Education and Teaching International, 45 (1), 55-65.

Christiansen, E. T., Kuure, L., Mørch, A., \& Lindström, B. (Eds.) (2013). Problem- based learning for the 21st century: New Practices and Learning Environments. (1 ed.) Aalborg Universities forlag. General.

Ertmer, P. A., \& Simons, K. D. (2006). Jumping the PBL implementation hurdle: Supporting the efforts of $\mathrm{K}-12$ teachers. The Interdisciplinary Journal of Problem-Based Learning, $1,1-15$.

Kingsley, C. (2019). Research methods and basic statistics: Paradigms in education, science and technology. Tripple K Production.

Krajcik, J. S., \& Shin, N. (2014). Project-based learning. In R . K. Sawyer (Ed.).The Cambridge handbook of the learning sciences (2 ed.) (pp. 275-297).Cambridge University Press.

Larmer, J. (2014). Project-based learning vs. problem-based learning vs. X-BL. Edutopia, George Lucas Educational Foundation.

MacMath, S. Sivia A. \& Britton, V. (2017). Teacher perceptions of project-based learning in the secondary classroom. Alberta Journal of Educational Research, 63 (2), 1.

Oliveira, A. M., Santos S. C., Garcia V. C. (2013), PBL in teaching computing: An overview of the Last 15 Years, FIE, Oklahoma, EUA. 
Santos, S. C., Batista, M. C. M., Cavalcanti, A. P. C., Albuquerque J. \& Meira S. R. L. (2009). Applying PBL in software Engineering Education. CSEET, Hyderabad.

Savery, J. (2015). Overview of problem-based learning: Definitions and distinctions. In A. E.

Victor-Ishikaku, E.C. \& Nyenwe, J. (2014). Teachers' knowledge of climate change impacts in secondary schools in Rivers State, Nigeria. International Journal of Education Learning and Development, 2 (3), 18-24.

Walker, A. E., \& Leary, H. (2009). A problem-based learning meta-analysis: Differences across problem types, implementation types, disciplines, and assessment levels. Interdisciplinary Journal of Problem-Based Learning, 3, 12-43.

Walker, H. Leary, C. E. Hmelo-Silver, \& P. A. Ertmer (Eds.), Essential Readings in Problem-based Learning 1, 5-16. 